\title{
Pharmacological, antioxidant, genotoxic studies and modulation of rat splenocyte functions by Cyperus rotundus extracts
}

\author{
Kilani-Jaziri Soumaya ${ }^{1,2}$, Mhalla Dhekra1,2, Châbane Fadwa ${ }^{1,2}$, Ghedira Zied ${ }^{1,2}$, Limem Ilef ${ }^{1,2}$, Ghedira Kamel \\ and Chekir-Ghedira Leila ${ }^{1 *}$
}

\begin{abstract}
Background: Cyperus rotundus Linn. (Cyperaceae) is a Tunisian medicinal plant used in folkloric (traditional) medicine to treat stomach disorders and inflammatory diseases. The present study explored the analgesic, anti-inflammatory and genotoxic activities of extracts from the aerial parts of $C$. rotundus. The antioxidant capacity and the modulation of splenocyte functions by these extracts were also investigated in mice. The phytochemical analysis was carried out using standard methods.
\end{abstract}

Methods: Aqueous, ethyl acetate, methanol and TOF-enriched extracts (300, 150, and $50 \mathrm{\mu g} / \mathrm{ml}$ ) were evaluated for their analgesic and anti-inflammatory activities. 4,2 , and $1 \mathrm{mg} / \mathrm{ml}$ of each extract were tested to investigate their effect on lipid peroxidation. The genotoxic study was monitored by measuring the structural chromosome aberrations of mice treated with $300 \mathrm{mg} / \mathrm{kg}$ of extract. The proliferation of lymphocytes in the absence and presence of mitogens was assessed at a concentration range $1-1000 \mu \mathrm{g} / \mathrm{ml}$.

Results: The tested extracts were able to decrease the mouse ear oedema induced by xylene. Furthermore, it was shown that the same extracts reduced the number of abdominal contractions caused by acetic acid in mice, revealing the peripheral analgesic activity of these extracts. It is worth noting that mice treated with doses up to $300 \mathrm{mg} / \mathrm{kg}$ b.w. of Cyperus rotundus extracts did not exhibit any toxicity. The tested extracts significantly enhance lymphocyte proliferation at $1 \mathrm{mg} / \mathrm{ml}$.

Conclusions: It appears that C. rotundus extracts contain potent components such as flavonoids that may potentially be useful for modulating the immune cell functions, provoking analgesic, anti-inflammatory and antioxidant effects.

Keywords: Cyperus rotundus, Analgesic activity, Anti-inflammatory activity, Lipid peroxidation effect, Chromosome aberrations, Immunomodulatory effect

\section{Background}

Tunisia is a rich source of medicinal plants, and a number of plant derived extracts are used to fight against various diseases. Only few plants have been scientifically explored. Plant derived natural products such as alkaloids, tannins, terpenes and flavonoids have received considerable attention in the recent years due to their

\footnotetext{
* Correspondence: leila.chekir@laposte.net

${ }^{1}$ Laboratoire de Biologie Cellulaire et Moléculaire, Faculté de Médecine dentaire de Monastir, Université de Monastir, Rue Avicenne, Monastir 5000, Tunisie

Full list of author information is available at the end of the article
}

diverse pharmacological properties including their analgesic, anti-inflammatory and antioxidant activities [1].

Pain is a pathophysiological response of the living tissue to undesirable stimuli. Inflammation can be defined as a reaction of a living cell or tissue to injury, infection or irritation/infiltration. It is characterized by swelling, redness and heat/fever. It can be induced by conditions that bring about the release of inflammatory mediators such as histamine, prostaglandins, nitric oxide, serotonin, cytokinines, leukotrienes, platelet activating factors and substance $\mathrm{P}$ [2]. In order to reduce the inflammatory response and damage to the human body,

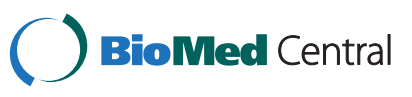


much effort has been made in the search for natural immunomodulatory products [3]. The pharmacology of pain has become a complex field. More recently, completely synthetic compounds based on natural pharmacophores have been introduced into the market but, research and medical fields still struggle with the sideeffect profiles from these analgesic substances that are undesirable. Therefore, the development of newer and more substantial analgesic drugs with fewer side-effects is necessary.

Cyperus rotundus Linn, a sedge of the family of Cyperaceae, order cyperales, is widely distributed in the Mediterranean basin areas. This plant, which grows naturally in tropical, subtropical and temperate region, is widespread in the North-East, Center and South of Tunisia [4]. C. rotundus is a traditional medicinal plant appearing among the Indian, Chinese and Japanese natural drugs .It is used in the treatment of spasms, stomach disorder and inflammatory diseases [5-7]. Zhu et al. [8] described the ulcer inhibitory effect of decoction from the rizhomes of $C$. rotundus, related to the inhibition of gastric motility. Other pharmacological investigations have indicated that $C$. rotundus, has remarkable hypotensive [9] and antipyretic effects [10].

The aim of this study was to validate the phytochemical groups, the anti-inflammatory, analgesic and antioxidant effects of the different extracts from Cyperus rotundus aerial parts. Besides, we investigated the immunomodulatory activity of the same extracts on lymphocyte proliferation as well as their genotoxicity by measuring the chromosome aberrations in bone marrow cells.

\section{Method}

\section{Plant material}

Cyperus rotundus aerial parts were collected from the region of Monastir, located in the Center of Tunisia, in October 2008. The botanical identification was carried out by Prof. Med Chaieb (Department of Botany, Faculty of Sciences, University of Sfax, Tunisia), according to the flora of Tunisia [4]. A voucher specimen (Cp.10-08) is kept in the laboratory of Pharmacognosy, Faculty of Pharmacy of Monastir, for future references.

\section{Preparation of plant extracts}

The fresh aerial parts of Cyperus rotundus were dried at room temperature and reduced to coarse powder. $100 \mathrm{~g}$ of the powdered leaves were boiled in water for 15 to $20 \mathrm{~min}$. The crude extract obtained was filtered and lyophilized (aqueous extract). The residue was dissolved in water.

In order to obtain an extract enriched with Total Oligomer Flavonoids (TOF), $100 \mathrm{~g}$ of powder were macerated in water/acetone mixture $(1 \mathrm{v} / 2 \mathrm{v})$ for 24 hours with continuous stirring. The extract was filtered and the acetone was evaporated under low pressure in order to obtain an aqueous phase. The tannins were partially removed by precipitation with an excess of $\mathrm{NaCl}$ for 24 hours at $5^{\circ} \mathrm{C}$, then we recovered the supernatant. The latter was extracted with ethyl acetate, concentrated and precipitated with an excess of chloroform. The precipitate was separated and yielded TOF enriched extract which was dissolved in water.

Ethyl acetate and methanol extracts were obtained by soxhlet extraction $(6 \mathrm{~h})$. The two types of extracts, with different polarities, were concentrated to dryness and the residue was kept at $4^{\circ} \mathrm{C}$. These two extracts were resuspended in DMSO.

\section{Quantitative analysis of extracts}

\section{Determination of total polyphenol and flavonoid content}

The polyphenol content of Cyperus rotundus extracts was quantified by the Folin-Ciocalteau reagent $[11,12]$. Aliquots of test samples $(100 \mu \mathrm{l})$ were mixed with $2.0 \mathrm{ml}$ of $2 \% \mathrm{Na}_{2} \mathrm{CO}_{3}$ and incubated at room temperature for $2 \mathrm{~min}$. After the addition of $100 \mu \mathrm{l} 50 \%$ Folin-Ciocalteau phenol reagent, the reaction tube was further incubated for $30 \mathrm{~min}$ at room temperature, and finally absorbance was read at $720 \mathrm{~nm}$. Gallic acid $(0.2 \mathrm{mg} / \mathrm{ml})$ was used as a standard. A known volume of each extract was placed in a $10 \mathrm{ml}$ volumetric flask to estimate flavonoid content according to the modified method of Zhishen et al. [13]. Distilled water was added to make the volume $5 \mathrm{ml}$, and then $0.3 \mathrm{ml} \mathrm{NaNO}$ aliquot $(1: 20 \mathrm{w} / \mathrm{v})$ was added to this dilution. Three milliliters of $\mathrm{AlCl}_{3}(1: 10 \mathrm{w} / \mathrm{v})$ were added $5 \mathrm{~min}$ later. After a 6 - min incubation, $2 \mathrm{ml}$ of $1 \mathrm{~N}$ $\mathrm{NaOH}$ was added to the mixture and the total absorbance was measured at $510 \mathrm{~nm}$ [12]. Quercetin was used as standard for constructing a calibration curve.

\section{Determination of tannin content}

The method described by Pearson [14] was used for the determination of tannin content of the samples. The extraction of tannin in the sample was achieved by dissolving $5 \mathrm{~g}$ of the sample in $50 \mathrm{ml}$ of distilled water in a conical flask, allowing the mixture to stand for $30 \mathrm{~min}$ with shaking of the flask at 10-min intervals, and then centrifuging at $5000 \mathrm{rpm}$ for $15 \mathrm{~min}$ to obtain a supernatant (tannin extract). The extract was diluted to $100 \mathrm{ml}$ in a standard flask using distilled water. Five milliliters of the diluted extract and $5 \mathrm{ml}$ of standard tannic acid $(0.1 \mathrm{~g} / \mathrm{L})$ were measured into different $50-\mathrm{ml}$ volumetric flasks. One milliliter of Folin- Denis reagent was added to each flask, followed by $2.5 \mathrm{ml}$ of saturated sodium carbonate solution. The solutions were made up to the $50-\mathrm{ml}$ mark with distilled water and incubated at room temperature for $90 \mathrm{~min}$ [15]. The absorption of these solutions was measured against that of the reagent blank (containing only $5 \mathrm{ml}$ of distilled water) in a Beckmann spectrophotometer at $760 \mathrm{~nm}$ wavelength. Tannin content (tannic acid equivalents) was calculated in 
triplicate and the concentration of tannin in the extract was determined using pure tannic acid as standard.

\section{Animals}

Balb/c mice (6-8 week-old males, 20-30 g) were obtained from the Pasteur Institute (Tunis, Tunisia). The animals were housed in polypropylene cages with stainless steel grill tops and provided with bedding of clean paddy husk. The animals were acclimatized to laboratory conditions for one week prior to treatment. The temperature in the animal room was maintained between $25 \pm 2^{\circ} \mathrm{C}$ with a relative humidity of $30-70 \%$ and illumination cycle set to $12 \mathrm{~h}$ light and $12 \mathrm{~h}$ dark. The mice were fed with standard laboratory pelleted feed. All animal experiments were performed in accordance with the guidelines for the care and use of laboratory animals published by the US National Institutes of Health. The study protocol was approved by the Ethics Committee of the University Hospital Fattouma-Bourguiba of Monastir, Tunisia.

\section{Acute toxicity}

Mice were randomly divided into groups of 5 animals and treated by i.p. injection: a first control group was given solvent Tween-80 (1\%) and a second control group was treated with Tween-80 (5\%). In fact, aqueous, methanol and TOF-enriched extracts were dissolved in Tween-80 (1\%), whereas ethyl acetate extract was dissolved in Tween-80 (5\%). The other groups of animals were treated by different doses of extracts, ranging from $125 \mathrm{mg} / \mathrm{kg}$ to $1 \mathrm{~g} / \mathrm{kg}$ body weights. The number of dead animals was followed every day for one week after treatment.

\section{Analgesic study: acetic acid-induced writhing assay}

The analgesic effect was tested according to the method described by Shibata et al. [16]. The abdomen writhing is a model of visceral pain and it was produced by i.p. injection of $1 \%(\mathrm{v} / \mathrm{v})$ acetic acid solution (volume of injection $0.1 \mathrm{ml} / 10 \mathrm{~g}$ b.w.) to each mouse, $30 \mathrm{~min}$ after the administration of the the aqueous, the TOF-enriched extract, ethyl acetate and methanol extracts (50, 150, $300 \mathrm{mg} / \mathrm{kg}$, b.w, respectively). Tween-80 (1\%, v/v) was used as negative control and diclofenac sodium was used as positive control $(100 \mathrm{mg} / \mathrm{kg}$, b.w.). After the immediate injection of acetic acid, each mouse was isolated in an individual observation box and the number of writhes produced in these animals was counted for $15 \mathrm{~min}$.

The percentage analgesic activity was calculated as follows:

$$
\text { Percentage analgesic activity }=\frac{\mathrm{N}-\mathrm{N}^{t} \times 100}{N}
$$

Where $\mathrm{N}$ is the average number of stretching of control animals per group
And $\mathrm{N}^{\mathrm{t}}$ is the average number of stretching of treated animals per group.

\section{Anti-inflammatory study: xylene-induced ear oedema}

The mice were divided into groups of five. Thirty minutes after i.p. injection of the extract (50 to $300 \mathrm{mg} / \mathrm{kg}$, b.w.) or dexamethasone (positive control) (300 mg/kg, b.w.), $0.03 \mathrm{ml}$ of xylene was applied to the anterior and posterior surfaces of the right ear. The left ear was considered as control. Two hours after xylene application, the mice were sacrificed and both ears were removed. Circular sections were taken using a cork borer with a diameter of $7 \mathrm{~mm}$, and were later weighed. The increase in weight caused by the irritant was measured by subtracting the weight of the untreated left ear section from that of the treated right ear sections. The oedema was quantified as the weight difference between the two earplugs. The antiinflammatory activity was evaluated as percent oedema reduction/inhibition in the treated animals relative to the control animals $[17,18]$ using the relation:

$$
\text { Oedema reduction inhibition } \%=100 \times(R t-L t) /
$$

Where $R \mathrm{t}=$ mean weight of the right ear plug of the treated animals; $L t=$ mean weight of the left ear plug of the treated animals; $R c=$ mean weight of the right ear plug of the control animals; $L c=$ mean weight of the left earplug of the control animals.

\section{Evaluation of lipid peroxidation by the thiobarbituric acid (TBA) assay}

TBA reacts with malondialdehyde (MDA) to form a diadduct, pink chromogen, which can be detected spectrophotometrically at $532 \mathrm{~nm}$ [19]. Normal male mice were used for the preparation of liver homogenate. The perfused liver was isolated, and $10 \%(\mathrm{w} / \mathrm{v})$ homogenate was prepared with homogenizer at $0-4^{\circ} \mathrm{C}$ with $0.15 \mathrm{M} \mathrm{KCl}$. The homogenate was centrifuged at $800 \mathrm{rpm}$ for $15 \mathrm{~min}$ and clear cell-free supernatant was used for the study of in vitro lipid peroxidation. One $\mathrm{ml}$ of $0.15 \mathrm{M} \mathrm{KCl}, 0.1 \mathrm{ml}$ of rat liver homogenate, $100 \mu \mathrm{l}$ of ascorbic acid $(0.5 \mathrm{mM})$ and $0.2 \mathrm{ml}$ of each extract concentration ( 1 to $4 \mathrm{mg} / \mathrm{ml}$ ) were mixed and the peroxidation reaction was initiated by adding $100 \mu \mathrm{l}$ of $15 \mathrm{mM} \mathrm{FeSO}_{4}$. After the incubation at $37^{\circ} \mathrm{C}$ for $1 \mathrm{~h}$, the reaction was stopped by adding $500 \mu \mathrm{l}$ of trichloroacetic acid (TCA) $(28 \%, \mathrm{w} / \mathrm{v})$ and $380 \mu \mathrm{l}$ TBA $(2 \%, w / v)$. This final mixture was heated in a water bath for $20 \mathrm{~min}$ at $80^{\circ} \mathrm{C}$, then it was cooled, centrifuged and the absorbance of the supernatant was measured at $532 \mathrm{~nm}$. The inhibition percentage of lipid peroxidation was calculated by comparing the results of lipid peroxidation obtained with liver homogenates 
treated with $\mathrm{FeSO}_{4}$ and extracts to those of controls treated only with $\mathrm{FeSO}_{4}$, by using the following formula:

$$
\begin{aligned}
& \text { Inhibition of lipid peroxidation }(\%) \\
& =(\text { Absorbance control }- \text { Absorbance test }) / \\
& \quad \text { Absorbance control } \times 100 \text {. }
\end{aligned}
$$

\section{Cell preparation from mice}

Spleen Balb/c lymphocytes were obtained as previously reported [20]. Briefly, 8-week-old male Balb/c mice were killed by cervical dislocation. The spleen was isolated, aseptically removed and homogenized by mincing with a sterile forceps. The splenocytes were harvested by centrifugation (1500 rpm, for $10 \mathrm{~min}$ ), and red blood cells were lysed with a lysis buffer $\left(144 \mathrm{mM} \mathrm{NH}_{4} \mathrm{Cl}, 1.7 \mathrm{mM}\right.$ Tris Base). The cells were washed twice with phosphatebuffered saline (PBS), resuspended in complete RPMI medium and adjusted to $5 \times 10^{6} \mathrm{cell} / \mathrm{ml}$. The cell incubation was conducted at $37^{\circ} \mathrm{C}$, in $5 \% \mathrm{CO}_{2}$ enriched atmosphere.

\section{Cell proliferation assay}

The evaluation of lymphocyte proliferation was carried out by using the MTT [3-(4,5- dimethylthiazol-2-yl)-2,5diphenyltetrazolium bromide] coloration method [21]. One hundred microliter of splenocyte suspension $\left(3 \times 10^{6}\right.$ cells $/ \mathrm{ml}$ ) in a 96-well plate were preincubated in RPMI 1640 medium (Control) for $24 \mathrm{~h}$ before the addition of mitogens (LPS and lectin at $5 \mu \mathrm{g} / \mathrm{ml}$ ), alone or with increasing concentrations of each extract (1, 0.1, 0.01, $0.001 \mathrm{mg} / \mathrm{ml}$ ) solubilized in RPMI. The cells were incubated at $37^{\circ} \mathrm{C}$ in humidified $5 \% \mathrm{CO}_{2}$ atmosphere for additionally $24 \mathrm{~h}$. After centrifugation at $1500 \mathrm{rpm}$ for $10 \mathrm{~min}$, the cell pellet was re-suspended in $50 \mu \mathrm{l}$ of MTT $(5 \mathrm{mg} / \mathrm{ml}$ ) in RPMI media and incubated for $4 \mathrm{~h}$ at $37^{\circ} \mathrm{C}$ in humidified $5 \% \mathrm{CO}_{2}$ atmosphere. The culture medium was removed after centrifugation and dimethylsulfoxide was added. The absorbance was measured at $570 \mathrm{~nm}$.

The percentage of proliferation was calculated by the following equation:

$$
\begin{aligned}
\text { Proliferation }(\%)= & ((\text { OD sample }- \text { OD control }) / \\
& (\text { OD control })) \times 100
\end{aligned}
$$

\section{Chromosome aberrations assay}

The aim of this experiment was to investigate if C. rotundus extracts exhibit a genotoxic effect, using animal models. Blab/c mice were used (average body weight $20 \pm 0.3 \mathrm{~g}$; age: 6 weeks old). These mice were given a standard granulated food and drinking water, and were divided into four groups with 5 mice each, as follows:
- Group 1: Mice given Tween-80 (1\%).

- Group 2: Mice given Tween-80 (5\%).

- Group 3: Mice given $40 \mathrm{mg} / \mathrm{kg}$ b.w. of methyl methane sulfonate (MMS), as positive control.

- Group 4: Mice given $300 \mathrm{mg} / \mathrm{kg}$ b.w. of Cyperus rotundus extracts.

The animals within the different treatment groups were given a subcutaneous injection of yeast suspension, dissolved in water $(20 \mathrm{mg} / \mathrm{ml})$, to accelerate the mitosis of bone marrow cells [22]. Ten minutes later, they received a single intraperitoneal $(\mathrm{I} / \mathrm{P})$ injection of the tested substance solution $(200 \mu \mathrm{l}$ of MMS, Cyperus rotundus extracts or Tween-80). Twenty-four hours later, the different animals were sacrificed by cervical dislocation. $200 \mu \mathrm{l}$ of vinblastin $(250 \mu \mathrm{g} / \mathrm{ml})$ were injected (I/P injection) to animals $45 \mathrm{~min}$ utes before they were sacrificed in order to block the dividing cells in metaphase. The cells of the bone marrow were collected from femurs and tibias, shielded with a hypotonic shock solution $(\mathrm{KCl} 0.075 \mathrm{M})$, then harvested in the presence of a methanol-acetic acid mixture 3/1 (v/v) (3 repetitions) by centrifugation at $1200 \mathrm{rpm}$ for $10 \mathrm{~min}-$ utes, according to the technique described by Evans et al. [23]. The cells were spread on glass slides that were blazed on a flame for $5 \mathrm{~s}$, then air-dried for conservation at room temperature and finally stained with a $4 \%(\mathrm{v} / \mathrm{v})$ Giemsa solution in water, for $15 \mathrm{~min}$ [24]. After coding slides, the chromosomes of 100 cells blocked in metaphase were examined for chromosome abnormalities at a magnification of $100 \times$ using an optical microscope (Olympus, France). Three replicates (300 metaphases per dose level) for each controls and treated groups were conducted. The chromosome aberrations were identified according to the criteria described by Savage [25]. The metaphases with chromosome breaks, gaps, rings and centric fusions were recorded and expressed as percentage of total metaphases per group.

\section{Statistical analysis}

Data are expressed as mean \pm SD (Standard Deviation). The biological activity was examined in three individual experiments, performed in triplicate for each dose. The statistical significance was determined using the Student's t-test. $\mathrm{P}<0.05$ was considered as indicative of significance as compared to the control group.

\section{Results}

Chemical preliminary study and metabolite content evaluation of Cyperus rotundus extracts

The chemical preliminary study of Cyperus rotundus extracts showed the presence of flavonoids, tannins and polyphenols. The Folin-Ciocalteu method is a rapid and widely-used assay investigating the total phenolic content, but it is known that different phenolic compounds 
Table 1 Quantitative polyphenol, flavonoid, and tannin contents of extracts from C. rotundus aerial parts

\begin{tabular}{ccccc}
\hline Metabolites & \multicolumn{3}{c}{ Extracts } \\
\hline Yields $(\%, w / w)$ & TOF enriched extract & Methanolic extract & Aqueous extract & Ethyl acetate extract \\
Polyphenols (gallic acid equivalents) $^{\mathrm{a}}$ & 0.16 & 13.12 & 13.7 & 1.52 \\
Flavonoids (quercetin equivalents) $^{\mathrm{a}}$ & $700 \pm 56$ & $355 \pm 7$ & $220 \pm 28$ & $175 \pm 21$ \\
Tannins (tannic acid equivalents) $^{\mathrm{a}}$ & $1610 \pm 77$ & $320 \pm 4$ & $316 \pm 15$ & $315 \pm 14$ \\
\hline
\end{tabular}

a: means of three experiments.

gave different responses with this method [26]. Therefore, we expressed the total polyphenol content of the extracts as gallic acid equivalents [27] following confirmation of linearity of the response of the assay using the extracts. The total flavonoid content of the C. rotundus extracts was determined by the method of Zhishen et al. [13]. The results summarized in Table 1 reveal that TOF-enriched extract exhibited the most important flavonoid and total polyphenolic contents, followed by methanolic, aqueous and ethyl acetate extracts. The aqueous extract showed the highest extracting yield (13.7\%), whereas the TOF enriched extract showed the lowest one $(0.16 \%)$ (Table 1$)$.

It appears that $1 \mathrm{mg}$ of TOF-enriched extract contains an amount of polyphenols equivalent to $700 \mu \mathrm{g}$ of gallic acid and an amount of flavonoids equivalent to $1610 \mu \mathrm{g}$ of quercetin. However, $1 \mathrm{mg}$ of each of ethyl acetate, methanolic and aqueous extracts contains respectively up to 175,355 and $220 \mu \mathrm{g}$ equivalent of gallic acid and 315, 320 and $316 \mu \mathrm{g}$ equivalent of quercetin. The highest content of tannin was recorded in both ethyl acetate and aqueous extracts, with respectively, 200.84 $\mu \mathrm{g}$ and $82.51 \mu \mathrm{g}$ equivalent of tannic acid. Yet, the methanolic and TOF-enriched extracts tannin contents were respectively, equivalent to 62.86 and $46.25 \mu \mathrm{g}$ of tannic acid.

\section{Acetic acid-induced writhing assay}

When administered (I/P) to mice, the different doses of the extracts $(50,150$ and $300 \mathrm{mg} / \mathrm{kg}$ ) provoke reduction of writhing response induced by acetic acid administered intraperitonally to mice (Table 2), in a dose-dependent manner. The inhibition percentages of writhing obtained with aqueous, ethyl acetate and methanolic extracts were $65.7 \%, 63 \%$ and $43 \%$, respectively at the same dose (300 mg/kg, b.w.). The TOF-enriched extract showed the most significant inhibitiory effect $(92.8 \%$ at the dose of $300 \mathrm{mg} / \mathrm{kg} \mathrm{b.} \mathrm{w.).} \mathrm{The} \mathrm{standard} \mathrm{analgesic} \mathrm{diclofenac}$ sodium (100 mg/kg, b.w.) reduced the abdominal constriction to $100 \%$.

\section{Xylene-induced mouse ear oedema assay}

The aqueous, ethyl acetate, methanolic and TOFenriched extracts from Cyperus rotundus administered at the dose of $300 \mathrm{mg} / \mathrm{kg}$, b.w showed a significant inhibiting effect against ear oedema induced by xylene. The inhibition percentages were $74.38 \%, 62.73 \%, 44.6 \%$ and $77.25 \%$, respectively, while the positive control, dexamethasone (300 mg/kg, b.w.) exhibited an inhibition percentage of ear oedema of $68.81 \%$ as shown in Table 3.

\section{Antioxidant activity}

The antioxidant activity of the plant extracts was evaluated by quantifying the ability of the different extract concentrations to suppress iron $\left(\mathrm{Fe}^{2+}\right)$-induced lipid peroxidation (LPO) in rat liver homogenate. In fact, the addition of $\mathrm{FeSO}_{4}$ in liver slices resulted in enhancing lipid peroxidation as observed earlier by other workers [28]. The initiation of $\mathrm{LPO}$ by $\mathrm{FeSO}_{4}$ is known to take place through ferryl perferryl complex [29]. The assessment of the extent of lipid peroxidation relied on individual determinations of MDA contents in sample

Table 2 Analgesic effect of the different extracts of Cyperus rotundus on acetic acid-induced writhings

\begin{tabular}{cccc}
\hline Treatment & $\begin{array}{c}\text { Doses } \\
(\mathbf{m g} / \mathbf{k g})\end{array}$ & $\begin{array}{c}\text { Acetic acid writhing } \\
\text { contraction }^{\mathbf{a}}\end{array}$ & $\begin{array}{c}\text { Percent } \\
\text { inhibition (\%) }\end{array}$ \\
\hline Control & - & $14 \pm 0,70$ & - \\
Diclofenac sodium & $\mathbf{2 5}$ & $10,33 \pm 4,04$ & $\mathbf{2 6 , 2 1}$ \\
& $\mathbf{5 0}$ & $1,5 \pm 0,7^{*}$ & $\mathbf{8 9 , 3 0}$ \\
TOF enriched extract & $\mathbf{1 0 0}$ & $0 \pm 0^{*}$ & $\mathbf{1 0 0}$ \\
& $\mathbf{5 0}$ & $5,4 \pm 0,54^{*}$ & $\mathbf{6 1 , 4 2}$ \\
Aqueous extract & $\mathbf{1 5 0}$ & $3,2 \pm 0,83^{*}$ & $\mathbf{7 7 , 2}$ \\
& $\mathbf{3 0 0}$ & $1 \pm 1^{*}$ & $\mathbf{9 2 , 8}$ \\
Ethyl acetate extract & $\mathbf{5 0}$ & $11 \pm 1,58^{*}$ & $\mathbf{2 1 , 5}$ \\
& $\mathbf{5 0}$ & $8 \pm 0,70^{*}$ & $\mathbf{4 2 , 9}$ \\
& $\mathbf{1 5 0}$ & $8,8 \pm 0,83^{*}$ & $\mathbf{6 5 , 7}$ \\
& $\mathbf{3 0 0}$ & $5,2 \pm 1,2 \pm 1,33^{*}$ & $\mathbf{2 8 , 6}$ \\
Methanolic extract & $\mathbf{5 0}$ & $8 \pm 2,88$ & $\mathbf{4 1 , 4}$ \\
& $\mathbf{1 5 0}$ & $11,2 \pm 1,92^{*}$ & $\mathbf{6 3}$ \\
& $\mathbf{3 0 0}$ & $8 \pm 1^{*}$ & $\mathbf{1 0}$ \\
\hline
\end{tabular}

${ }^{\text {a }}$ Values are expressed as mean \pm standard deviation ( $n=5$ animals). ${ }^{*} \mathrm{P}<0,05$ compared to corresponding control (Student's $t$-test). 
Table 3 Effect of the extracts from Cyperus rotundus on xylene-induced ear edema in mice

\begin{tabular}{cccc}
\hline Treatment & Doses $(\mathbf{m g} / \mathbf{k g})$ & Edema $_{(\mathbf{m g})^{\mathbf{a}}}$ & Inhibition (\%) \\
\hline Control & - & $61,12 \pm 7,44$ & - \\
Dexamethasone & $\mathbf{5 0}$ & $49,46 \pm 1,95^{*}$ & $\mathbf{1 9 , 0 8}$ \\
& $\mathbf{1 5 0}$ & $37,9 \pm 2,57^{*}$ & $\mathbf{3 8 , 4 8}$ \\
& $\mathbf{3 0 0}$ & $19,06 \pm 1,61^{*}$ & $\mathbf{6 8 , 8 1}$ \\
TOF enriched extract & $\mathbf{5 0}$ & $37,46 \pm 4,7^{*}$ & $\mathbf{3 8 , 7 1}$ \\
& $\mathbf{1 5 0}$ & $25,38 \pm 3,35^{*}$ & $\mathbf{5 8 , 4 7}$ \\
Aqueous extract & $\mathbf{3 0 0}$ & $13,9 \pm 1,79^{*}$ & $\mathbf{7 7 , 2 5}$ \\
& $\mathbf{5 0}$ & $42,52 \pm 2,72^{*}$ & $\mathbf{3 0 , 4 3}$ \\
Ethyl acetate extract & $\mathbf{1 5 0}$ & $28,9 \pm 2,01^{*}$ & $\mathbf{5 2 , 7 1}$ \\
& $\mathbf{3 0 0}$ & $15,66 \pm 1,05^{*}$ & $\mathbf{7 4 , 3 8}$ \\
& $\mathbf{5 0}$ & $35,26 \pm 1,97^{*}$ & $\mathbf{4 0 , 7 7}$ \\
Methanolic extract & $\mathbf{1 5 0}$ & $30,24 \pm 1,33^{*}$ & $\mathbf{5 0 , 5 2}$ \\
& $\mathbf{3 0 0}$ & $22,78 \pm 1,19^{*}$ & $\mathbf{6 2 , 7 3}$ \\
& $\mathbf{5 0}$ & $50,76 \pm 3,48^{*}$ & $\mathbf{1 6 , 9 5}$ \\
& $\mathbf{1 5 0}$ & $44,98 \pm 3,05^{*}$ & $\mathbf{2 6 , 4 1}$ \\
& $\mathbf{3 0 0}$ & $33,86 \pm 2,10^{*}$ & $\mathbf{4 4 , 6}$ \\
\hline
\end{tabular}

a Values are expressed as mean \pm standard deviation ( $n=5$ animals). ${ }^{* P}<0,05$ compared to corresponding control (Student's $t$-test).

supernatants by performing the TBARS assay, as described by Draper and Hadley [30]. MDA is an end product of peroxidative decomposition of polyenoic fatty acids by the lipid peroxidation process. Its accumulation in tissues is indicative of the extent of lipid peroxidation [30]. Ex vivo experiments showed that different concentrations $(1,2,4 \mathrm{mg} / \mathrm{ml})$ of each extract produced dosedepending inhibitory effects on lipid peroxidation induced in rat liver cells (Figure 1). $\mathrm{IC}_{50}$ values of MDA formation were $1.3 \mathrm{mg} / \mathrm{ml}$ in the presence of the aqueous extract, $1.2 \mathrm{mg} / \mathrm{ml}$ in the presence of the methanolic extract and $1.7 \mathrm{mg} / \mathrm{ml}$ in the presence of

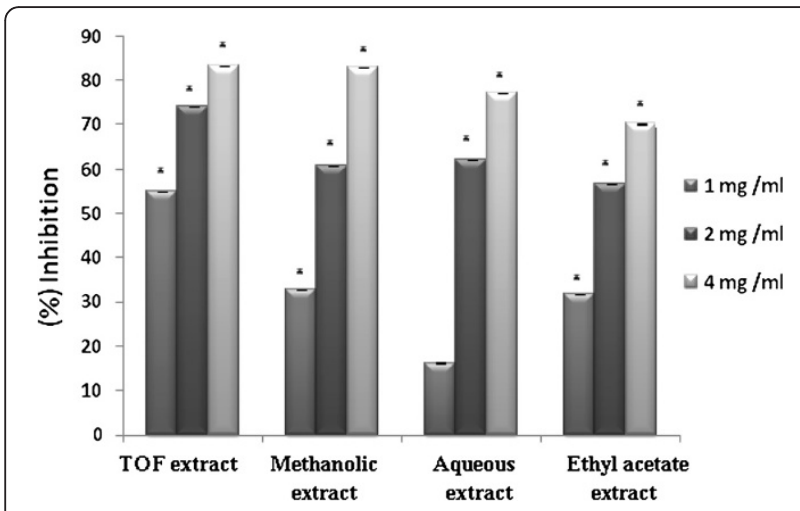

Figure 1 Anti-lipid peroxidation activity of different extracts from Cyperus rotundus. Data represented as mean \pm standard error of three replicated experiment. Values in each line with asterisks $\left(^{*}\right)$ are significantly different $(P<0.05)$. the ethyl acetate extract. The TOF-enriched extract $\left(\mathrm{IC}_{50}=0.75 \mathrm{mg} / \mathrm{ml}\right)$ exhibited the most significant lipid peroxidation inhibitory effect as compared to the others extracts. Thus, it is notable that lipid peroxidation (LPO) inhibition capacity of the extracts increases as the extract concentrations increase.

\section{Acute toxicity testing}

The different extracts of Cyperus rotundus did not exhibit acute toxicity up to the dose of $1 \mathrm{~g} / \mathrm{kg}$ b.w. The weight of the treated mice varied normally after 7 days of observation. The common side effects such as mild diarrhea, loss of weight and depression were not recorded. In fact, the mice treated with doses up to $300 \mathrm{mg} / \mathrm{kg}$ b.w. of C. rotundus extracts exhibited significant antiinflammatory and analgesic activities. For this reason, we attempted to investigate whether this dose would provoke any genotoxic effect.

\section{Genotoxicity evaluation using the chromosome aberration assay}

The metaphasic chromosome slides were observed for structural aberrations. The observations revealed the presence of centric fusions, rings and chromosomal breaks (Table 4). The positive control (MMS) was found to induce statistically significant number of structural aberrations, mainly centric fusions, rings and chromosome breaks in bone marrow cells. The treatment of animals with the different extracts at $300 \mathrm{mg} / \mathrm{kg}$ b.w. for $24 \mathrm{~h}$ did not induce significant number of chromosome aberrations when compared to the negative control. These data indicate that $C$. rotundus extracts exhibit no genotoxic activity, and thus support the safety of $C$. rotundus extracts at the tested dose.

\section{Mitogen-induced splenocyte proliferation}

The lymphocyte-mediated immunity plays an important role in the cellular and humoral immune responses. The capacity to elicit an effective T- and B-lymphocyte immunity can be shown by the stimulation of lymphocyte proliferation response. It is generally known that Lectin stimulates T cells and LPS stimulates B cell proliferation $[31,32]$. In this study, we investigated the effects of the aerial part extracts from C. rotundus, on lymphocyte proliferation with and without mitogen stimulation. In the absence of mitogens, all the dose-dependently extracts stimulate splenocyte proliferation compared to untreated cells. As shown in Figure 2-A, maximums of cell proliferation were observed at a concentration of $1 \mathrm{mg} / \mathrm{ml}$ of aqueous extract (86.06\%), ethyl acetate extract (126.22\%), methanolic extract (249\%) and TOFenriched extract (260.11\%). When we treated the mouse splenocytes with mitogen, we also observed a stimulation of cell proliferation. A dose of $5 \mu \mathrm{g} / \mathrm{ml}$ LPS 
Table 4 Different types of chromosomal damage induced by MMS (40 mg/kg b. w.) and different extracts (300 mg/kg b.w.) from Cyperus rotundus in bone marrow cells of male Balb/c mice

\begin{tabular}{cccccccc}
\hline \multicolumn{1}{c}{ Treatment } & ctb & csb & del & r & cf & ra & Total aberrations $^{\text {a }}$ \\
\hline Solvent control : Tween-80 (1\%) & - & 1 & - & 6 & 6 & - & $13 \pm 0.58$ \\
Methyl methansulfonate (MMS) & - & 16 & - & 17 & 12 & - & $44 \pm 3.06$ \\
$\quad$ TOF enriched extract & - & 3 & - & 3 & 3 & - & $9 \pm 1.53$ \\
$\quad$ Aqueous extract & - & 4 & - & 4 & 2 & - & $10 \pm 0.62$ \\
$\quad$ Methanolic extract & - & - & - & 3 & 11 & - & $14 \pm 0,58$ \\
Solvent control : Tween-80 (5\%) & - & - & - & 10 & 7 & - & $17 \pm 1.15$ \\
$\quad$ Ethyl acetate extract & - & 2 & - & 12 & 5 & - & $19 \pm 1.53$ \\
\hline
\end{tabular}

$\mathrm{ctb}=$ chromatid break, csb = chromosome break, del = deletion, $\mathrm{r}=$ ring, $\mathrm{cf}=$ centric fusion, $\mathrm{ra}=$ rearrangements.

${ }^{a}$ Total aberrations (mean \pm standard error of the mean from one hundred cells were analyzed per animal for a total of 500 cells per treatment).

stimulates cell proliferation by $50.82 \%$, whereas a dose of $5 \mu \mathrm{g} / \mathrm{ml}$ of lectin stimulates proliferation by $69.67 \%$. In the presence of lectin, the different extracts elicited an increase in splenocyte proliferation by $139.8 \%, 227 \%, 236.88 \%$ and $293.44 \%$ at $1 \mathrm{mg} / \mathrm{ml}$, respectively (Figure 2-B), compared to the untreated cells. In the presence of LPS, the extracts at $1 \mathrm{mg} / \mathrm{ml}$ enhanced the proliferation of splenocytes by $193.44 \%, 323.7 \%$, 303.28\% and $391.8 \%$ with respectively the same extracts (Figure 2-C), compared to the untreated cells. A dose of $1 \mathrm{mg} / \mathrm{ml}$ of each extract exhibits no toxicicity on mouse splenocytes as it was revealed by MTT assay (survival rates higher than 90\%).

\section{Discussion}

Previous studies conducted by our team revealed the presence of catechin, afzelechin and galloyl quinic acid in TOF-enriched extract from the aerial parts of C. rotundus, and luteolin, ferulic acid, quercetin, 3hydroxy, 4-methoxybenzoic acid and 6,7 dimethoxycoumarin in the ethyl acetate extract [33]. Among these secondary compounds, belonging to either tannin, polyphenol or flavonoid families, several are known to exhibit antinociceptive and anti-inflammatory effects [34,35], and we believe that the analgesic and anti-inflammatory activities we observed with extracts from the aerial parts of Cyperus rotundus should be ascribed to such compounds. Besides, i.p. administration of different doses (125 mg/kg to $1 \mathrm{~g} / \mathrm{kg}$ b.w.) of Cyperus rotundus extracts to mice gives no toxic effect. This finding suggests that the plant extracts are, at the tested doses, safe in mice.

The peripheral analgesic effect may be mediated through the inhibition of cyclo-oxygenases and/or lipoxygenases (and other inflammatory mediators) [36]. This hypothesis is in accordance with those of Adeyemi et al. [37] and Zhang et al. [38], who have postulated that acetic acid-induced writhing is a highly sensitive and useful test for analgesic drug development, especially peripherally acting analgesics. Acetic acid induces pain by liberating endogenous substances (bradykinin, serotonin, histamine, substance P) [39], which in turn excite the pain nerve endings. In our observation, aqueous, methanolic, ethyl acetate and TOF-enriched extracts significantly $(\mathrm{P}<0.001)$ reduced the abdominal constriction response induced by the acetic acid in a dose-dependent manner. TOF-enriched extract exhibited the most analgesic potency, whereas methanolic extract showed the weakest one. This result could be explained by the presence of active compounds diluted and/or masked by various components in the methanolic extract and which are more accessible and/or more concentrated in the TOFenriched extract. Besides, this test is useful for the evaluation of mild analgesic non steroidal, anti-inflammatory compounds $[40,41]$. This suggests a peripherally induced mechanism of the analgesic action for Cyperus rotundus extracts [42]. Therefore, one possible mechanism of the analgesic activity by $C$. rotundus extracts could be due to the blockage of the effect, or the release of endogenous substances (arachidonic acid metabolites) that excite pain nerve endings by the pharmacologically active principles of $C$. rotundus extracts. From a mechanistic point of view, the lack of specificity in acetic acid-induced writhing test suggests the involvement of different nociceptive mechanisms in the reduction of muscular constriction, such as sympathetic system, through the release of biogenic amines, cyclooxygenases and their metabolites inhibition, and through opioids receptors mechanisms [43].

In evaluating the anti-inflammatory effect, it is important to estimate the activities of the extracts in the acute phase as well as in the chronic phase of inflammation. Xylene-induced ear oedema in mice was selected to evaluate acute anti-inflammatory activity and is a good in vivo test useful for evaluating lipoxygenase inhibitors and partially associated with substance $P$ [44]. The results in Table 3 showed that the different extracts of C. rotundus caused significant inhibition of oedema as compared to the control group. These results may suggest that the plant extracts exert significant antiinflammatory activity, especially in the acute inflammatory response. The suppression of this response is a 

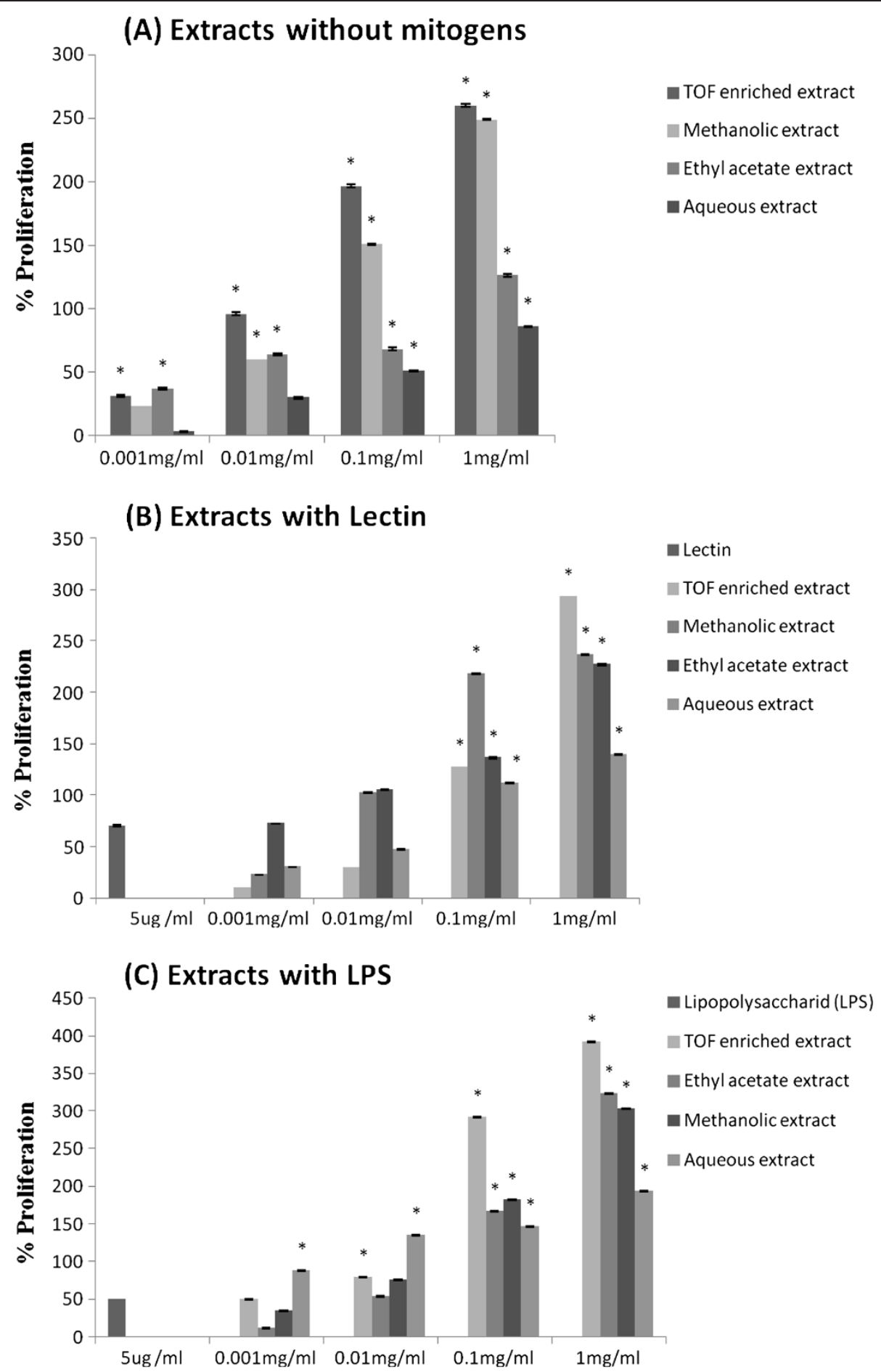

Figure 2 Effects of different extracts from Cyperus rotundus on in vitro proliferation response of splenocytes: (A) Cells were incubated with extract without mitogens, (B) cells were treated with extracts in the presence of $5 \mu \mathrm{g} / \mathrm{ml}$ lectin, and (C) Cells were treated with extracts in the presence of $\mathbf{5} \mathbf{\mu g} / \mathbf{m l}$ LPS. Cell proliferation was assessed by the MTT test. The data plotted represent average \pm standard deviation of triplicates. Values in each line with asterisks $\left(^{*}\right)$ are significantly different $(P<0.05)$. 
likely indication of the antiphlogistic effect [45]. The topical anti-inflammatory effect suggests that constituents of the extract may relieve rheumatism and offer the additional advantage of suppressing inflammatory response initiated by tissue injury when the leaves are used in folkloric treatment of arthritis and wounds respectively [46]. In fact, the activity may be related to the inhibition of inflammatory mediators such as histamine, serotonin, bradykinin, and prostaglandins.

On the other hand, the anti-inflammatory and analgesic activities of many plant extracts have been attributed to their high sterol/triterpene [47] or flavonoid contents [34]. Other studies have demonstrated that various flavonoids such as rutin, quercetin, luteolin, hesperidin and biflavonoids produced significant antinociceptive and/or antiinflammatory activities [48]. On the basis of these results, it can be concluded that the different extracts of C. rotun$d u s$ possess antinociceptive and anti-inflammatory activities and this may be due to any one or a combination of their phytochemical constituents [33].

The difference in significance between ethyl acetate and TOF-enriched extracts concerning the analgesic and anti-inflammatory activities may be due to their different constituents. Several compounds obtained from $C$. rotundus extracts were identified as catechin, luteolin, quercetin and ferulic acid [33]. Previous reports indicated that various flavonoids have an antiinflammatory activity [48] suggesting that flavonoids should be responsible for the anti-inflammatory and analgesic effects obtained with the different $C$. rotundus tested extracts. In addition, we previously showed that ethyl acetate extract contains sterols [49], which are documented as anti-inflammatory constituents $[50,51]$.

Several medicinal plants are considered immunomodulatory as they display a variety of anti-inflammatory, antimicrobial and antitumoral effects [20]. The modulation of immune cell activities by molecules from medicinal plant origin is an area of active interest for inflammation, autoimmunity and cancer therapy. Investigating the effects of substances that promote or inhibit lymphocyte inflammatory response represents a potent means to study immunomodulation and drug discovery. In the present study, lymphocytes isolated from mice were used as models because of their critical role in controlling innate and immune inflammatory responses [52]. Lymphocytes are the key effector cells of mammalian adaptive immune system and our studies show that the different subpopulations of lymphocytes are differentially activated by Cyperus rotundus extracts at varying levels. The extracts significantly increased the proliferation of splenocytes at concentrations of $1-1000 \mu \mathrm{g} / \mathrm{ml}$, and these effects were markedly enhanced in the presence of LPS. The concomitant presence of lectin and extracts $(1 \mathrm{mg} / \mathrm{ml})$ enhance splenocyte proliferation, except with the methanolic extract. Lectin acts directly on lymphocyte $\mathrm{T}$ cells, which are involved in cell mediated immunity, while LPS acts on lymphocyte B cells that are responsible for humoral immune response [20]. Therefore, C. rotundus extracts could enhance both cellular and humoral immunity depending on the concentrations. A dose of $1 \mathrm{mg} / \mathrm{ml}$ stimulates cellular and humoral immunity. In fact, lymphocyte B cell proliferation as well as lymphocyte $T$ cell response are stimulated by both high and low extract concentrations. We believe that phenolic compounds, especially flavonoids, might contribute to the immunomodulatory effects of C. rotun$d u s$ extracts and their anti-inflammatory activity.

Injury of the mucous membranes cells may provoke the production of active oxygen species. The latter can directly injure the surrounding cells and extracellular matrices, such as hyaluronic acid, and produce lipid peroxides and metabolites of arachidonic acid. In general, active oxygen species are thought to promote inflammation through these processes [53]. On the other hand, antioxidants, such as superoxide dismutase and catechins, are known to suppress inflammation. Antioxidants may offer resistance against the oxidative stress by scavenging the free radicals, inhibiting the lipid peroxidation, and/or by other mechanisms, and thus preventing some diseases [54]. The different extracts of $C$. rotundus exhibited important antioxidant activities. The results obtained in the present study may be attributed to several reasons viz: the inhibition of ferrylperferyyl complex formation; scavenging of $\mathrm{OH}$ or superoxide radicals or by changing the ratio of $\mathrm{Fe}^{3+} / \mathrm{Fe}^{2+}$; reducing the conversion rate of ferrous to ferric iron or by chelating of the iron itself. The antioxidant activity of the extracts may probably be due to the rapid and extensive degradation of the oxidant principles in an ex vivo state. In our study, there seems to be a good correlation between the phenolic content and antioxidant activity of the extracts, since the TOF-enriched extract with higher phenolic content showed the highest antioxidant activity. However, it is known that nonphenolic antioxidants could also contribute to the antioxidant activity of an extract. Thus, we strongly believe that the anti-inflammatory activity revealed by $C$. rotundus plant extracts, should be ascribed, at least in part, to their antioxidant activity as far as radical-induced actions play a central role in the inflammatory condition. Thus, the antioxidant and free radical scavenging flavonoids could prevent generation of inflammatory mediators [55].

Based on these results, we chose to perform the genotoxicity assay on mice by numbering the chromosome aberrations in sample treated animal cells, and comparing them to control animal cells. The chromosomal aberrations (CA) are changes in chromosome structure resulting from a break or exchange of chromosomal material. Most of the CA observed in cells are lethal, but 
there are many aberrations that are viable and can cause genetic effects, either somatic or inherited [56]. Our study showed no induction of chromosome or chromatid aberrations in the cells obtained from animals treated with each tested extract. To explain this result, we propose the following hypotheses: [1] mutagenic compounds were deactivated in the animal body, [2] mutagenic compounds did not reach bone marrow cells, [3] C. rotundus extracts does not cause genetic damage at all, or does not cause genetic damage detected by using the chromosome aberrations assay.

\section{Conclusions}

The results of the present work clearly demonstrate the significant anti-inflammatory and peripheral analgesic activities of the different extracts from the aerial parts of Cyperus rotundus. The same extracts exhibited an antilipid peroxidation capacity. On the other hand, the tested extracts influence humoral-mediated immunity by stimulating B and T cell proliferation. These results indicate that Cyperus rotundus might have immunostimulatory properties that can be exploited in food and pharmaceutical industries. The analgesic, anti-inflammatory, antioxidant and immunomodulatory effects of the extracts may be ascribed to their flavonoid, tannin and polyphenol contents. The exact mechanism and the bioactive principles responsible for these actions still need to be explained. However, further in vivo studies are needed to evaluate the real use of these extracts in the anti-inflammatory and antioxidant therapeutics.

\section{Competing interests}

The authors declare that they have no competing interests.

\section{Authors' contributions \\ KJS carried out polyphenols, flavonoids and tannins quantification, photochemical analysis, extract preparation and chromosome aberrations assay. MD carried out analgesic assay. CF carried out anti-inflammatory assay. GZ carried out lipid peroxidation assay. LI prepared solutions which have been used for splenocyte proliferation assay. GK assisted with Cyperus rotundus extraction and study design and interpretation. CGL helped conceive the study and helped in the preparation of the manuscript. All authors read and approved the final manuscript.}

\section{Acknowledgments}

The authors thank the Tunisian Ministry of higher Education, Scientific Research and Technology for the financial support of this study. They are grateful Pr. Hassen BACHA the head of laboratory for Research on Biologically Compatible Compounds, Faculty of Dentistry and all members of this laboratory for their help in culture cell experiments.

\section{Author details}

'Laboratoire de Biologie Cellulaire et Moléculaire, Faculté de Médecine dentaire de Monastir, Université de Monastir, Rue Avicenne, Monastir 5000, Tunisie. ${ }^{2}$ Unité de Pharmacognosie/Biologie Moléculaire 99/UR/07-03. Faculté de Pharmacie de Monastir, Université de Monastir, Rue Avicenne, Monastir 5000, Tunisie.

\section{References}

1. Pandurangan A, Khosa RL, Hemalatha S: Evaluation of anti-inflammatory and analgesic activity of root extract of Solanum trilobatum Linn. Iran J Pharmaceut Res 2008, 7:217-221.

2. Payne DO: Nitric oxide in allergic air way inflammation. Curr Opin Allergy Clin Immunol 2003, 3(2):133-137.

3. Hackett $\mathrm{CJ}$ : Innate immune activation as a broad-spectrum biodefense strategy: prospects and research challenges. J Allergy Clin Immunol 2003, 112:686-694.

4. Cuénod A: Flore de la Tunisie: cryptogames vasculaires, gymnospermes et monocotylèdones. Tunis: Office de l'expérimentation de la vulgarisation agricoles de Tunisie; 1954.

5. Gupta MB, Palit TK, Singh N, Bhargava KP: Pharmacological studies to isolate the active constituents from Cyperus rotundus possessing antiinflammatory, anti-pyretic and analgesic activities. Indian J Med Res 1971, 59:76-82.

6. Seo WG, Pae HO, Oh GS, Chai KH, Kwon TA, Yun YG, Kim NY, Chung HT: Inhibitory effect of methanol extract of Cyperus rotundus rhizomes on nitric oxide and superoxide productions by murine macrophage cell line, RAW 264.7 cells. J Ethnopharmacol 2001, 76:59-64.

7. Singh N, Kulshrestha VK, Gupta MB, Bhargava KP: A pharmacological study of Cyperus rotundus. Indian J Med Res 1970, 58:103-109.

8. Zhu M, Luk HH, Fung HS, Luk CT: Cytoprotective effects of Cyperus rotundus against ethanol induced gastric ulceration in rats. Phytother Res 1997, 11:392-394.

9. Li GX: Pharmacology, Toxicity and Clinic of Traditional Chinese Medicine. Tianjin: Tianjin Science and Technique Translation Publishing House; 1992:194-195.

10. Vedavathy S, Rao KN: Antipyretic activity of six indigenous medicinal plants of Tirumala hills. India J Ethnopharmacol 1990, 33:193-196.

11. Yuan WY, Bone DE, Carrington FF: Antioxidant activity of dulse (Palmaria palmata) extract evaluated in vitro. Food Chem 2005, 91:485-494.

12. Chattopadhyay SK, Kumar S: Identification and quantification of two biologically active polyisoprenylated benzophenones xanthochymol and isoxanthochymol in Garcinia species using liquid chromatographytandem mass spectrometry. J Chromatogr B 2006, 844:67-83.

13. Zhishen J, Mengcheng $T$, Jianming $W$ : The determination of flavonoid contents in mulberry and their scavenging effects on superoxide radicals. Food Chem 1999, 64:555-559.

14. Pearson D: The Chemical Analysis of Foods. London: Churchill Livingstone 1976.

15. Nwabueze TU: Effect of process variables on trypsin inhibitor activity (TIA) phytic acid and tannin content of extruded African breadfruit-cornsoy mixtures: a response surface analysis. Lebensm Wiss Technol 2007, 40:21-29.

16. Shibata S, Kumagai A, Harada M, Yano S, Saito H, Takahashi K: United States Patent 1983, 4374284:7-10.

17. Tubaro A, Dri P, Delbello G, Zilli C, Delia LR: The croton oil ear test revisited. Agents Actions 1985, 17:347-349.

18. Asuzu IU, Sosa S, Delila LR: The anti-inflammatory activity of Icacina trichantha tuber. Phytomedicine 1999, 6:267-272.

19. Singh R, Singh B, Singh S, Kumar N, Kumar S, Arora S: Investigation of ethyl acetate extract/fractions of Acacia nilotica Willd. Ex Del as potent antioxidant. Rec Nat Prod 2009, 3:3:131-138.

20. Limem-Ben Amor I, Harizi H, Ghedira K, Chekir-Ghedira L: Leaf extracts from Phlomis crinita Cav. subs. mauritanica Munby affect immune cell functions in vitro. Immunopharmacol Immunotoxicol 2011, 33:309-314.

21. Mossmann T: Rapid colorimetric assay for cellular growth and survival: application to proliferation and cytotoxicity assays. J Immunol Methods 1983, 65:55-63.

22. Zorgui L, Boussema Yl, Ayed $Y$, Bacha H, Hassen W: The antigenotoxic activities of cactus (Opuntia ficus-indica) cladodes against the mycotoxin zearalenone in Balb/c mice: prevention of micronuclei, chromosome aberrations and DNA fragmentation. Food Chem Toxicol 2009, 47:662-667.

23. Evans EP, Breckon G, Ford CE: An air drying method for meiotic preparation from mammalian tests. Cytogenetics 1960, 3:613-616.

24. Abbès $S$, Ouanes $Z$, Ben Salah-Abbès J, Abdel-Wahhab MA, Oueslati $R$, Bacha $\mathrm{H}$ : Preventive role of aluminosilicate clay against induction of micronuclei and chromosome aberrations in bone-marrow cells of Balb/ c mice treated with Zearalenone. Mutat Res 2007, 631:85-92.

25. Savage JRK: Classification and relationship of induced chromosomal structural changes. J Med Genet 1975, 12:103-122. 
26. Kahkonen MP, Hopia Al, Vuorela HJ, Rauha JP, Pihlaja K, Kujala TS, Heinonen M: Antioxidant activity of plant extracts containing phenolic compounds. J Agric Food Chem 1999, 47:3954-3962.

27. Capecka EM, ALeja M: Antioxidant activity of fresh and dry herbs of some Lamiaceae species. Food Chem 2005, 93:223-226.

28. Braughler JM, Duncan LA, Chase RL: The involvement of iron in lipid peroxidation. Imporatnce of ferric to ferrous iron in initiation. J Biol Chem 1986, 261:10282-10289.

29. Gutteridge JMC: Age pigments and free radicals: fluorescent lipid complexes formed by iron and copper containing proteins. Biochem Biophys Acta 1985, 834:144-151.

30. Draper $\mathrm{HH}$, Hadley M: Malondialdehyde determination as an index of lipid peroxidation. Methods Enzymol 1990, 186:421-431.

31. Manosroi A, Saraphanchotiwitthaya A, Manosroi J: In vitro immunomodulatory effect of Pouteria cambodiana (Pierre ex Dubard) Baehni extract. J Ethnopharmacol 2005, 101:90-94.

32. Han SB, Kim YH, Lee CW, Park SM, Lee HY, Ahn KS, Kim IH, Kim HM: Characteristic immunostimulation by angelan isolated from Angelica. Int Immunopharmacol 1998, 40:39-48.

33. Kilani-Jaziri S, Neffati A, Limem I, Boubaker J, Skandrani I, Ben Sghair M Bouhlel I, Bhouri W, Mariotte AM, Ghedira K, Dijoux Franca MG, ChekirGhedira L: Relationship correlation of antioxidant and antiproliferative capacity of Cyperus rotundus products towards K562 erythroleukemia cells. Chem Biol Interact 2009, 181:85-94.

34. Parmar NS, Ghosh MMN: Current trends in flavonoid research. Indian J Pharmacol 1978, 12:213-228.

35. Ramesh M, Rao YN, Rao AV, Prabhakar MC, Rao CS, Muralidhar N, Reddy BM: Antinociceptive and anti-inflammatory activity of a flavonoid isolated from Caralluma attenuata. J Ethnopharmacol 1998, 62:63-66.

36. Nunez-Guillèn ME, da Silva Emin JA, Souccar C, Lapa AJ: Analgesic and anti-inflammatory activities of the aqueous extract of Plantago major $L$. Int J Pharmacogn 1997, 35:99-104.

37. Adeyemia $\mathrm{O}$, Yemitan OK, Afolabi L: Inhibition of chemically induced inflammation and pain by orally and topically administered leaf extract of Manihot esculenta Crantz in rodents. J Ethnopharmacol 2008, 119:6-11.

38. Zhang L, Hu JJ, Lin JW, Fang WS, Du GH: Anti-inflammatory and analgesic effects of ethanol and aqueous extracts of Pterocephalus hookeri (C.B. Clarke) Hoeck. J Ethnopharmacol 2009, 123:510-514.

39. Tsung-Chun $L$, Yu-Zen $K$, Hsin-Wei H, Ying-Chun $H$, Ying-Chih L, Wen- Huang $P$ : Analgesic and anti-inflammatory activities of aqueous extract from Glycine tomentella root in mice. J Ethnopharmaco/ 2007, 113:142-148.

40. Ferreira SH, Vane JR: New aspects in the mode of action of non-steroidal anti-inflammatory drugs. Annu Rev Pharmacol 1974, 14:57-73.

41. Berkenkopf JW, Weichman BM: Production of prostacyclin in mice following intraperitoneal injection of acetic acid, phenylbenzoquinone and zymosan: its role in the writhing response. Prostaglandins 1988, 36:693-709.

42. Santos ARS, Filho VC, Niero R, Viana AM, Morenof N, Campos MM, Yunes RA, Calixto JB: Analgesic effects of callus culture from selected species of Phyllantus in mice. J Pharm Pharmacol 1994, 46:755-759.

43. Andrade SF, Cardoso LGV, Carvalho JCT, Basteos JK: Anti-inflammatory and antinociceptive activities of extract, fractions and populnoic acid from bark wood of Austroplenckia populnea. J Ethnopharmacol 2007, 109:464-471.

44. Young JM, Young L: In Pharmacological Methods in the Control of Inflammation. Edited by Spector J, Back N. New York: Alan R. Li; 1989:215-231.

45. Atta AH, Alkohafi A: Antinociceptive and anti-inflammatory effects of some Jondanian medicinal plants extracts. J Ethnopharmacol 1998 60:117-124.

46. Okoli ACO, Akah PA, Nwafor SV, Anisiobi Al, Ibegbunam IN, Erojikwe O: Anti-inflammatory activity of hexane leaf extract of Aspilia africana C.D. J Ethnopharmacol 2007, 109:219-225.

47. Ahmed MM, Qureshi S, Al-Bekairi AM, Shah A, Rao RM, Qazi NS: Antiinflammatory activity of Caralluma tuberculata alcoholic extract. Fitoterapia 1993, 4:357-360.

48. Calixto JB, Beirith A, Ferreira J, Santos AR, Cechinel Filho V, Yunes RA Naturally occurring antinociceptive substances from plants. Phytother Res 2000, 14:401-418.

49. Kilani S, Ben Ammar R, Bouhlel I, Abdelwahed A, Hayder N, Ghedira-Chekir L: Investigation of extracts from (Tunisian) Cyperus rotundus as antimutagens and radical scavengers. Environ Toxicol Pharmacol 2005, 20:478-484.
50. Akihisa T, Yasukawa K, Kimura Y, Takase S, Yamanouchi S, Tamura T: Triterpene alcohols from camellia and sasanqua oils and their antiinflammatory effects. Chem Pharm Bull 1997, 45:2016-2023.

51. Park EH, Kahng JH, Lee $\mathrm{SH}$, Shin $\mathrm{KH}$ : Anti-inflammatory principles from Cactus. Fitoterapia 2001, 72:288-290.

52. Chen TL, Chang CC, Lin YL, Ueng YF, Chen RM: Signal-transducing mechanisms of ketamine-caused inhibition of interleukin-1 gene expression in lipopolysaccharide-stimulated murine macrophage-like Raw 264.7 cells. Toxicol Appl Pharmacol 2009, 240:15-25.

53. Oyanagui $Y$ : Various actions of active oxygens on inflammatory process. Jpn J Inflamm 1983, 3:377-378.

54. Sangameswaran B, Balakrishnan BR, Chumbhale D, Jayakar B: In vitro antioxidant activity of roots of Thespesia lampas Dalz and Gibs. Pak J Pharm Sci 2009, 22:368-372.

55. Rios JL, Manèz S, Paya M, Alcaraz MJ: Antioxidant activity of flavonoids from Sideritis javalambrensis. Phytochemistry 1992, 31:1947-1950.

56. Swierenga SHH, Heddle JA, Sigal EA, Gilman JPW, Brillinger RL, Douglas GR, Nestmann ER: Recommended protocols based on a survey of current practice in genotoxicity testing laboratories. IV. Chromosome aberrations and sister-chromatid exchange in Chinese hamster ovary, V79 Chinese hamster lung and human lymphocyte cultures. Mutat Res 1991, 246:301-322.

doi:10.1186/1472-6882-13-28

Cite this article as: Soumaya et al:: Pharmacological, antioxidant, genotoxic studies and modulation of rat splenocyte functions by Cyperus rotundus extracts. BMC Complementary and Alternative Medicine 2013 13:28

\section{Submit your next manuscript to BioMed Central and take full advantage of:}

- Convenient online submission

- Thorough peer review

- No space constraints or color figure charges

- Immediate publication on acceptance

- Inclusion in PubMed, CAS, Scopus and Google Scholar

- Research which is freely available for redistribution 